\title{
Teaching medical ethics in Basra: perspective of students and graduates
}

A.A-H. Yacoub' and N.A-H. Ajeel'

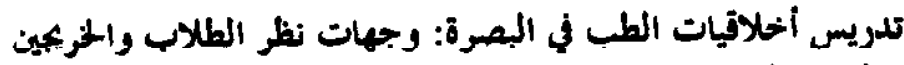

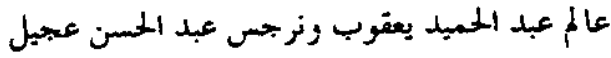

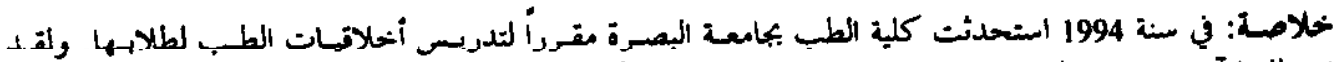

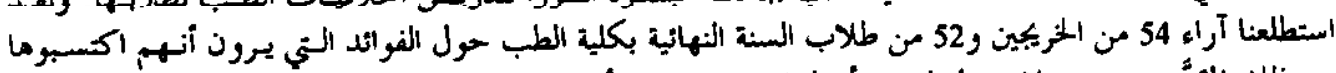

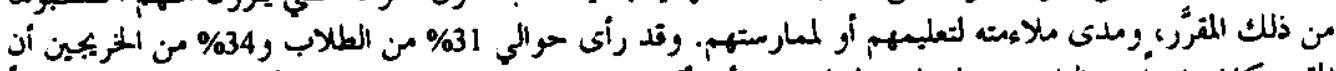

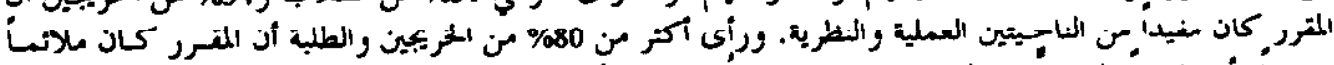

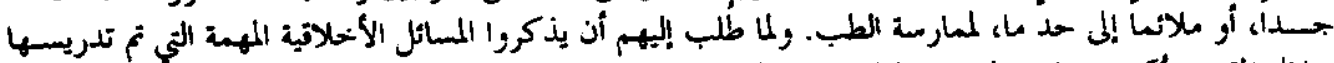

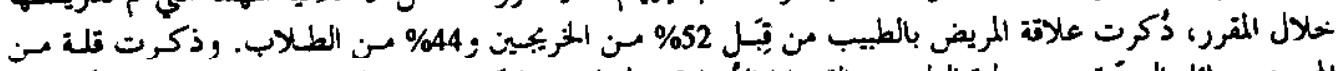

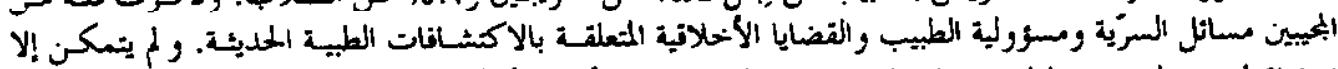

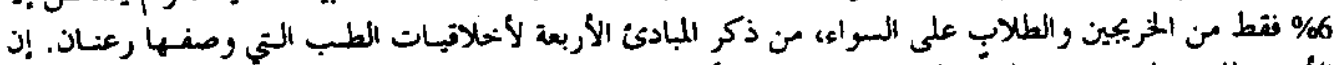

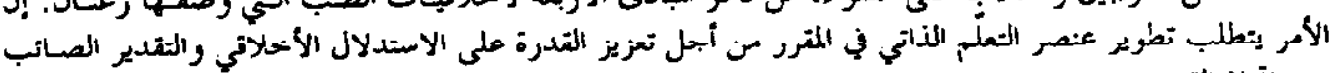
عند اتختاذ الأقراراته

ABSTRACT The University of Basra Medical College introduced a course on medical ethics for undergraduate students in 1994. We explored the opinions of 54 graduates and 52 final-year medical students about the benefits they perceive they gained from the course and its relevance to their training or practice. About $31 \%$ of students and $34 \%$ of graduates thought the course was practically and theoretically useful. Over $80 \%$ of graduatos and students thought the ooureo was oither very rolevant or relevant to some oxtont to the practice of medicine. When asked to recall the important ethical issues taught in the course, $52 \%$ of graduates and $44 \%$ of students fisted patient-doctor reiationship. Confidentiality, physician liability and ethical issues concerning recent medical innovations were listed by few respondents. Only $6 \%$ of both graduates and students were able to list the four princlples of medical ethics as described by Raanan. The self-learning component of the course should be developed to strengthen ethical reasoning and judgment in decision-making.

\section{Enseignement de l'éthique médicale à Bassora : perspectlves des étudiants et des diplómés}

RESUME L'Université “ Basra Medical College " a introduit un cour's sur l'éthique medicale pour les erudiants en médecine en 1994. Nous avons exploré les opinions de 54 diplömés et de 52 étudiants en médecine en dernière année sur les avantages qu'ils perçoivent avoir tiré de leur cours et sa pertinence pour leur formation ou leur pratique. Près de $31 \%$ des étudiants et $34 \%$ des diplémés pensaient que le cour's átait utile sur le plan pratique et théorique. Plus de $80 \%$ des diplómés et étudiants pensaient que le cours était très important ou utile dans une certaine mesure pour la pratique de la médecine. Lorsqu'on leur demandait de rappeler les questions éthiques importantes enseignées durant le cours, $52 \%$ des diplómés et $44 \%$ des étudiants citaient la relation patient-módoein. La confidentialitó, la responeabilitó du módooin ot lee questione sthiques concernant les innovations médicales récentes étaient citées par queiques répondants. Seuls $6 \%$ des diplömés et des étudiants étaient capables d'énumérer les quatre principes de l'éthique médicale tels que Raanan les a décrits. La composante d'auto-apprentissage du cours devrait être développée pour renforcer le raisonnement et le jugement ethique dans la prise de decision.

'College of Medicine, University of Basra, Basra, Iraq.

Heceived: 03/02/00; accepted: 04/05/00

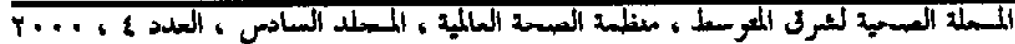




\section{Introduction}

The notion that ethical principles are not taught but assimilated from the attitudes of colleagues and teachers was reasonable when there was a close apprenticeship system [l]. However, such a notion is no longer tenable in light of the recent advances in medical practice and health technologies, and with the emergence of highly sophisticated organizational set-ups. It is now generally agreed that medical ethics should be an integral part of medical education throughout undergraduate, postgraduate and continuing education [2]. The main objective of teaching medical ethics is to ensure that the physician is sensitive to ethical issues in medical decision-making [2]. However, the content of medical ethics courses and the ways of teaching such courses vary considerably from country to country and within countries. For example, in a survey of medical faculties in Arab countries, it was found that medical ethics was taught as part of forensic medicine in the majority of faculties, while only a few taught the subject as an independent course [3].

The University of Basra Medical College introduced a 1-year independent course in medical ethics for undergraduate students in 1994. It consists of a series of lectures taught to the fourth-year medical students. The aim of the course is to raise the awareness of students about ethical issues in medical practice and to promote their ethical reasoning. We thought it was now appropriate to carry out an evaluation study to explore the opinions of students and graduates who were taught the course on the benefits they perceive they gained from the course and its relevance to their medical practice whether during their final year of clinical training or during their in- ternship. The present paper reports the results of the study.

\section{Methods}

\section{Course description}

The course consists of a series of introductory lectures (related to theories of ethics, ethical codes, principles of medical ethics, ethics in Islamic Arabic traditions) followed by lectures covering ethical issues in various disciplines and specialties of medicine. It also includes ethical issues raised by recent advances in medical biotechnology, such as genetic engincering, biological cloning and in vitro fertilization. The issues are discussed within the context of prevailing social values and noms.

In the past 2 years, in addition to lectures, students engage in project work, small group workshops and seminars. Every attempt is made to encourage faculty staff from various disciplines to participate in the teaching of the subject.

\section{Data collection}

Final-year (sixth-year) medical students and doctors doing their internship (usually within 2 years of graduation) were included in the study. Self-administered questionnaires were distributed to both groups. The study was carried out during the academic year 1997-1998. Both the final-year students and graduates had taken the ethics course when they were in the fourth year of their medical education. The questionnaire explored the following issues:

- The benefits the students and graduates considered they had derived from the course and its relevance to their career.

- The main topics they could remember which were relevant to their training and practice. 
- Their ability to list the four principles of medical ethics which they were taught (beneficence, non-maleficence, justice and autonomy).

- The extent to which these principles are followed in actual medical practice by their senior colleagues and by medical personnel.

- The importance of the following topics, which are included in the course, with respect to their training and practices:

- patient-doctor relationship

- ethical codes

- ethics in medical research

- ethics across history

- ethical issues in abortion

- ethical issues in paediatrio practice

- ethical issues in public health

- ethical theories.

- The extent to which selected aspects of ethical issues and professional conduct are emphasized during their clinical training by their clinical tutors.

\section{Results}

All 52 final-year medical students and 54 interns (out of 60 ) returned the questionnaires. Two of the interns said that they were not taught medical ethics and two others mentioned that it was taught within forensic medicine or other subjects. These four interns were graduates of other medical colleges where a formal course in medical ethics was not taught to medical students.

Table 1 shows the benefit derived from the course according to the respondents. In all, $34.0 \%$ of the graduates and $30.8 \%$ of the medical students thought that the course was theoretically and practically useful, while $6.0 \%$ and $9.6 \%$ of the graduates and students respectively thought it was not useful. When asked whether the subject was relevant to their practice of medicine, the majority of the graduates and students (83.0\% and $85.1 \%$ respectively) said they thought the course was very relevant or somewhat relevant (Table 2). Table 3 shows the topics the respondents recalled they were taught during the course. Patient-doctor relationship and doctor-doctor relation-

Table 1 Oplnions of the graduates and students about the benefit derived from the course on medical ethics

\begin{tabular}{lrrrrr}
\hline Response & \multicolumn{2}{c}{ Graduates } & \multicolumn{2}{c}{ Students } \\
& No. & \multicolumn{1}{c}{$\%$} & No. & $\%$ \\
\hline Theoretically useful & 17 & 34.0 & 12 & 23.1 \\
Theoretically and & & & & \\
$\quad$ practically useful & 17 & 34.0 & 16 & 30.8 \\
Of limited benefit & 13 & 26.0 & 19 & 36.5 \\
Not useful & 3 & 6.0 & 5 & 9.6 \\
Total & 50 & 100.0 & 52 & 100.0 \\
Not applicable & 4 & - & - & - \\
\hline
\end{tabular}

Table 2 Opinlons of the graduates and students about the relevance of the course to the practlce of medlcine

\begin{tabular}{|c|c|c|c|c|}
\hline Response & $\begin{array}{l}\text { Grad } \\
\text { No. }\end{array}$ & $\begin{array}{c}\text { uates } \\
\%\end{array}$ & $\begin{array}{l}\text { Stuc } \\
\text { No. }\end{array}$ & $\begin{array}{c}\text { Jents } \\
\%\end{array}$ \\
\hline Very relevant & 13 & 27.7 & 10 & 21.3 \\
\hline $\begin{array}{l}\text { Relevant to a } \\
\text { certain extent }\end{array}$ & 26 & 55.3 & 30 & 63.8 \\
\hline Not relevant & 3 & 6.4 & 4 & 8.5 \\
\hline No response & 5 & 10.6 & 3 & 6.4 \\
\hline Total & 47 & 100.0 & 47 & 100.0 \\
\hline Not applicable & 7 & - & 5 & - \\
\hline
\end{tabular}

- This includes the 4 graduates who had not attended the course and 3 graduates and 5 students who

mentioned that the course was not usaful 
Table 3 Topics the graduates and students recalled belng taught during the course

\begin{tabular}{|c|c|c|c|c|}
\hline Topic & $\begin{array}{l}\text { Grad } \\
(n=\end{array}$ & 50) & $\begin{array}{l}\text { Stud } \\
\langle n=\end{array}$ & \\
\hline & No. & $\%$ & No. & $\%$ \\
\hline $\begin{array}{l}\text { Patient-doctor } \\
\text { relationship }\end{array}$ & 26 & 52.0 & 29 & 55.8 \\
\hline $\begin{array}{l}\text { Relation between } \\
\text { doctor and other } \\
\text { medical staff }\end{array}$ & 23 & 46.0 & 11 & 21.2 \\
\hline Confidentiality & 7 & 14.0 & 7 & 13.5 \\
\hline $\begin{array}{l}\text { Ethical issues in } \\
\text { abortion }\end{array}$ & 5 & 10.0 & 12 & 23.1 \\
\hline Patient care & 6 & 12.0 & 6 & 11.5 \\
\hline $\begin{array}{l}\text { Relation between } \\
\text { doctor and } \\
\text { family of patient }\end{array}$ & 2 & 4.0 & 5 & 9.6 \\
\hline $\begin{array}{l}\text { Relation of doctor } \\
\text { to his/her tutors }\end{array}$ & 1 & 2.0 & 6 & 11.5 \\
\hline Law and modioine & 7 & 14.0 & 2 & 3.6 \\
\hline Physician liability & 5 & 10.0 & 2 & 3.8 \\
\hline
\end{tabular}

ship were listed by $52.0 \%$ and $46.0 \%$ respectively of the graduates and by $55.8 \%$ and $21.2 \%$ of the medical students respectively. Other topics, such as confidentiality, patient care and physician liability, were listed by fewer respondents. It is noteworthy that controversial and topical ethical issues, such as the ethical aspects of recent medical and technological developments, were not recalled by the respondents.

As regards the ability of the respondents to name the four cardinal principles of medical ethics (beneficence, non-maleficence, justice and autonomy), only 3 $(6.0 \%)$ of the graduates and $3(5.8 \%)$ of the students were able to list all four principles. We found $10(20.0 \%)$ graduates and 13 $(25.0 \%)$ students could list some of the priciples, $8(16.0 \%)$ graduates and $22(42.3 \%)$ students gave completely wrong answers and $29(58.0 \%)$ graduates and $14(26.9 \%)$ students did not answer this question; the question was not applicable to 4 graduates who had not attended the University of Basra.

When asked about the extent to which such principles are followed in actual medical practice, $33(66.0 \%)$ graduates and 38 $(73.1 \%)$ students thought that the principles were not observed in actual practice, $15(30.0 \%)$ graduates and $10(19.2 \%)$ students felt they were observed and $2(4.0 \%)$ graduates and $4(7.7 \%)$ students did not answer this question.

Table 4 shows the respondents' opinions about the theoretical and practical relevance of certain topics taught during the course. Patient-doctor relationship, and ethical issues in abortion and paediatric practice were considered relevant by the vast majority of both groups. A smaller majority considered ethics in medical research and ethics in public health relevant while ethics across history and ethical codes were not generally considered relevant.

\section{Discussion}

Students' perspective is considered an important component in the evaluation of medical education. In fact, the World Summit on Medical Education in 1993 emphasized the need to involve students as partners in all levels of medical education, including planning, curriculum development and evaluation [4]. It is within this context that the present study was carried out.

The aforementioned World Summit also stressed that teaching medical ethics should be considered an integral part of medical education. Our study has shown that although medical students appreciated to a 


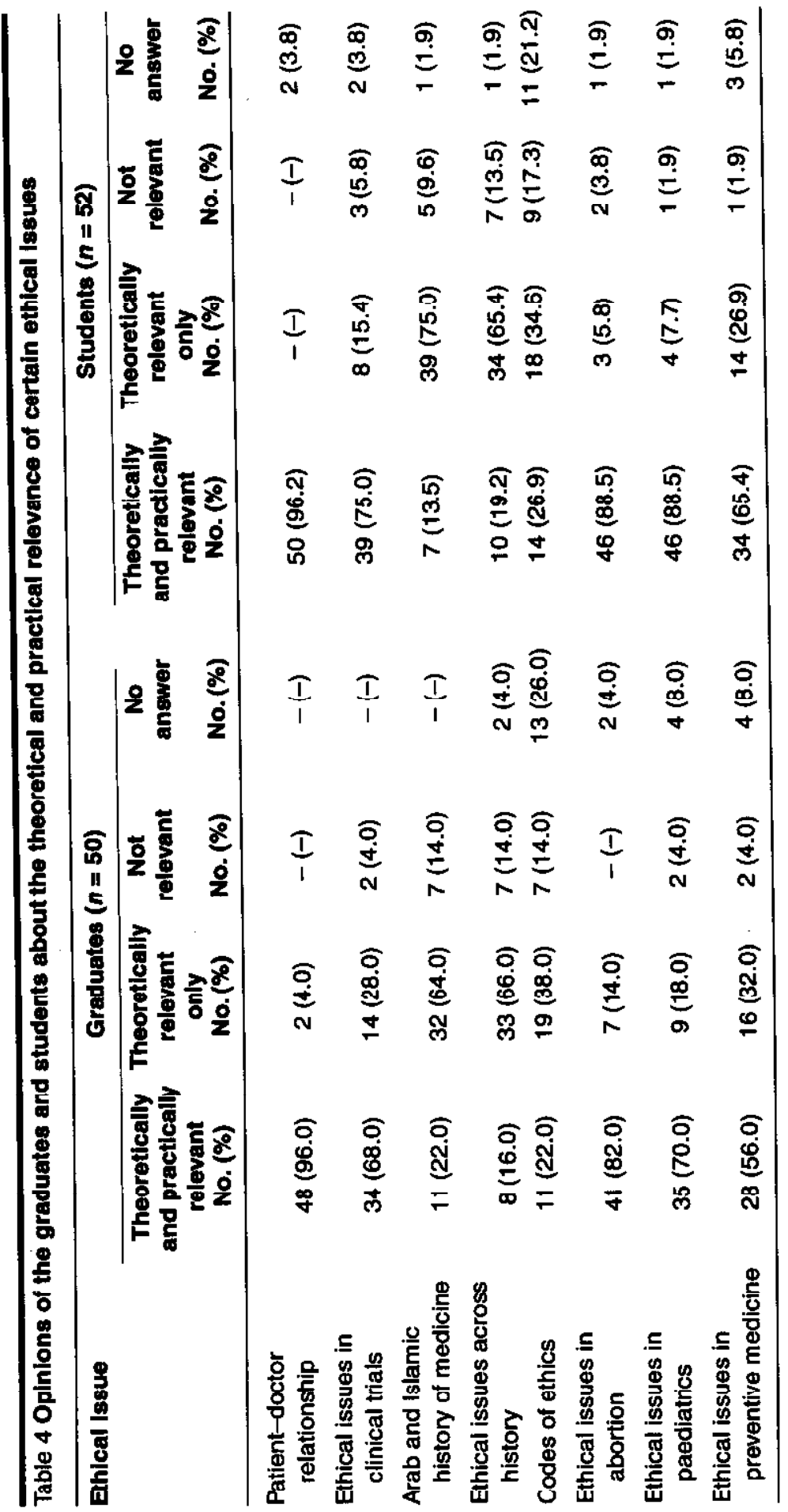


certain extent the course on medical ethics, they were unable to mention the four cardinal principles of medical ethics as emphasized by Kaanan [ 5 ].

In addition, when they were asked to recall topics they were taught during the course, important issues were missed, such as care of terminally ill patients and ethical issues related to recent developments. They also underestimated the importance of ethical issues in preventive medicine and codes of ethics. The predominantly didactic nature of the course might be responsible for this shortcoming. Thus, active student participation in workshops and seminars needs to be incorporated. Case-studies should also be developed as a source of learning. The didactic component should be limited to basic concepts and professional code of ethics as recommended by the World Health Organization report on teaching medical ethics [2].
In Basra College of Medicine, an attempt to incorporate project work and workshops in teaching medical ethics began 2 years ago. However, wider involvement of medical staff in teaching the subject is required. An earlier survey on the ethical reasoning of the medical staff in Basra indicated the need to develop their awareness of ethical issues in medical practice [6].

In conclusion, our survey of medical students and graduates in Basra showed that a formal course in medical ethics increases the awareness of students of ethical issues as evidenced by their appreciation of the importance and relevance of the subject. However, the study highlighted the need to develnp a self-learning component through case-studies, seminars and project work in order to strengthen ethical reasoning and judgment in decision-making.

\section{References}

1. Bliss B, Johnson A. Aims and motives in clinical medicine. London, Pitman Medical, 1975:3.

2. The teaching of medical ethics. Fourth consultation with leading medical practitioners, Geneva 12-14 October 1994. Geneva, World Health Organization, 1995.

3. El-Marti A. The teaching of medical ethics in the Arab countries. Results of a survey presented at a WHO meeting on teaching medical othice, Genova, 1005.
4. World Summit on Medical Education: the Changing Medical Profession. Edinburgh, World Federation for Medical Education, 1993:28-9.

5. Raanan G. Philosophical medical ethics. British medical journal, 1985, 290:11179, 1806-8.

6. Yacoub A. Ethical reasoning about aspects of medical practice among doctors in Basrah, southern Iraq. Basrah journal of surgery, 1995, 1:24-8. 